\title{
article CRITICAL ANALYSIS OF JOSÉ MARQUES DE MELO'S JOURNALISTIC THINKING
}

FRANCISCO RÜDIGER

Pontifícia Universidade Católica do Rio Grande do Sul, Porto Alegre - Rio

Grande do Sul - Brazil

ORCID: 0000-0002-1859-5394

OTÁVIO DAROS

Pontifícia Universidade Católica do Rio Grande do Sul, Porto Alegre - Rio

Grande do Sul - Brazil

ORCID: 0000-0003-0738-8207

DOI: 10.25200/BJR.v16n2.2020.1272

Received in: November $11^{\text {th }}, 2019$

Desk Reviewed: January $25^{\text {th }}, 2020$

Desk Review Editor: Claudia Lago

Revised on: March $5^{\text {th }}, 2020$

Approved on: May $11^{\text {th }}, 2020$

\begin{abstract}
A pioneer figure in the field, José Marques de Melo gained justified fame in journalism studies in Brazil, without elaborating upon a systematic reflection on the subject. In this article, we proceed to the rational reconstruction of what would be his journalism theory, in order to develop a critical judgment about its intellectual meaning and epistemological limits. We argue that his ideas are part of what will be referred to here as liberal-developmentalism. In conclusion, we affirm that the lack of greater scientific and intellectual resonance in his work is the result of the incompatibilities and contradictions of this kind of thinking with the historical formation of Brazilian society. Key words: José Marques de Melo. Journalism studies. Journalism theory. Brazilian thought. Liberal-developmentalism.
\end{abstract}

\section{ANÁLISE CRÍTICA DO PENSAMENTO JORNALÍSTICO DE JOSÉ MARQUES DE MELO}

RESUMO - Figura pioneira no campo, José Marques de Melo marcou posição nos estudos de jornalismo no Brasil, sem ter pretendido deixar reflexão sistemática a respeito do assunto. Procedemos neste artigo à reconstrução racional do que seria sua teoria do jornalismo para, no fim, emitir juízo crítico sobre seu significado intelectual e seus limites epistemológicos. Argumentamos que suas ideias se enquadram no que se chamará aqui de liberal- 
desenvolvimentismo. Em conclusão, afirmamos que a falta de maior ressonância científica e intelectual de sua obra é fruto das incompatibilidades e contradições do referido ideário com a formação histórica da sociedade brasileira.

Palavras-chave: José Marques de Melo. Estudos de jornalismo. Teoria do jornalismo. Pensamento brasileiro. Liberal-desenvolvimentismo.

\section{ANÁLISIS CRÍTICO DEL PENSAMIENTO PERIODÍSTICO DE JOSÉ MARQUES DE MELO}

RESUMEN - Figura pionera en el campo, José Marques de Melo marcó posición en los estudios de periodismo en Brasil, sin haber tenido la intención de elaborar una reflexión sistemática sobre el tema. En este artículo, procedemos a la reconstrucción racional de lo que sería su teoría del periodismo para, al final, emitir un juicio crítico sobre su significado intelectual y sus límites epistemológicos. Argumentamos que sus ideas caen dentro de lo que aquí se llamará liberal-desarrollismo. En conclusión, afirmamos que la falta de mayor resonancia científica e intelectual en su trabajo es resultado de las incompatibilidades y contradicciones de esa idea con la formación histórica de la sociedad brasileña.

Palabras clave: José Marqués de Melo. Estudios de periodismo. Teoría del periodismo. Pensamiento brasileño. Liberal desarrollismo.

\section{Introduction}

Among pioneering names, José Marques de Melo (1943-2018) was one of the most significant in the consolidation of journalism as an object of academic study in Brazil. Disciple of his predecessor Luiz Beltrão, he introduced and disseminated the subject in university circles, from a perspective that was both Brazilian and Latin American. A noteworthy academic for his leadership skills, he worked for several decades at the Universities of São Paulo, and at the Methodist University of São Bernardo do Campo, where, in 1996, he took on the role of Unesco Chair in Communication for Regional Development.

An important figure in the field of communication studies too (Cobbi, 2010), he came from journalism and, despite having introduced the subject to that field in his first years, he ultimately recognized the academic autonomy of journalism. Born in the state of Alagoas, he started writing for newspapers at the age of 15 , influenced by militancy in catholic youth movements. Having graduated in journalism and law 
at, respectively, the Catholic and Federal Universities of Pernambuco (1964/1965), he soon began to focus on academic research under the supervision of Luiz Beltrão, founder of the first academic center for studies in the field: the Information Science Institute at Catholic University (Marques de Melo, 2000).

Intimidated following participation in the Miguel Arraes' leftist local government, overthrown by the military coup of 1964 , Marques de Melo left the country to do postgraduate studies at the Centro Internacional de Estudios Superiores de Comunicación para América Latina (Ciespal), founded in Quito, Ecuador, with support from Unesco, in 1959. Returning to Brazil, he migrated to the economic center of the country, becoming a professor at the recently founded School of Communications and Arts at the University of São Paulo, where he was useful in creating the journalism department in 1967.

He was the first Brazilian academic to receive a doctoral degree in journalism (Marques de Melo, 1973; Sousa, 2018), but notwithstanding, he became a target of political persecution during the Military Regime, being exonerated from his position after finishing post-doctoral studies at the University of Wisconsin, United States (1973-1974). Forbidden to teach at public universities in Brazil, he worked at private schools, such as the Methodist University of São Bernardo do Campo, until he was politically amnestied and regained his former academic position (Marques de Melo, 2012b).

Having retired from the University of São Paulo in 1993, Marques de Melo continued to work as the Unesco Chair until he was forced to stop due to the degenerative disease that led to his death in 2018. We are interested in this article in analyzing only his theoretical contribution to journalism studies. We will not examine his institutional work and contributions to other fields. Undoubtedly meritorious, these feats have already been extensively treated by a vast body of literature, starting with the series Fortuna crítica (Aragão et al., 2013-2015). What is missing and what we will focus on in this study is a specific analysis of his intellectual contributions to the academic field of journalism.

Spreading a scientific research mentality in this field in Brazil according to the "Ciespalino spirit", Marques de Melo introduced journalism to the communication field during the 1960s (Marques de Melo, 1970). Revising his understanding, however, he spoke late against this understanding, since it would lead journalism "to a loss of professional identity and to a lack of characterization as a field 
of knowledge" (Marques de Melo, 2003, p.190)'. Marques de Melo was influenced by Ciespal scholars and learned from Jacques Kayser the methods of comparative study and analysis of morphological content for the press, becoming the main introducer of this academic approach in Brazil (Marques de Melo, 1972; Ferreira, 2013). When he regained his position at the University of São Paulo, however, his agenda added a concern with the issues of the press and information, the political scope and the significance of journalism in the national development of Brazil.

Sociologia da Imprensa Brasileira (1973), originally presented as the first journalism doctoral thesis defended in Brazil, may be seen as an initial framework to understand this movement, which continued until the "memorialistic turn" verified in his work in the early 2000s. In this last stage, Marques de Melo's work was characterized by a predominantly rhetorical use of classificatory procedure, aiming to organize and conceptualize information about names and ideas responsible for what he, as a self-declared historian, defined as Brazilian journalistic thinking (Marques de Melo, 2006).

Marques de Melo opposed what he described as being political-ideological journalistic thinking, at the same time that he adopted a perspective he called professional-criticism: i.e., "whose rationale [would be] offering contributions to improve the academic identity of journalism" (Marques de Melo, 2006, p.33). In the following, we will discuss this judgment as ideology, since the author's ideas, in our analysis, go far beyond the academic label he took for himself. We think it is not certain to say that, in his view, "in journalism studies journalism must be primarily thought from journalism itself" (Sousa, 2010, p.56).

Marques de Melo wrote prolifically on numerous topics in the academic field of communication but, except for one or another sketch (Marques de Melo, 1985, pp. 57-71, for example), he did not elaborate any journalism theory of a systematic nature ${ }^{2}$. There is nothing in his literature that, for example, resembles Luiz Beltrão's Iniciação à Filosofia do Jornalismo (1960) or Adelmo Genro Filho's $O$ Segredo da Pirâmide (1987). Does this mean that there is no way to examine the matter? We argue that this is not the case, since a more careful analysis of his work allows us to rationally reconstruct, if not a theory, at least one doctrine about journalism.

When approaching the final stage of his career, the author became the subject of a literary industry which was predominantly 
commemorative in nature. The four volumes of Fortuna crítica de José Marques de Melo, more than two thousand pages in total, written by dozens of Brazilian academics, for example, do not give us any epistemological examination and critical discussion of the author's academic work. The collections organized by Maria Cristina Cobbi (2001) and Antônio Hohlfeldt (2010) follow the same lines. The approach is invariably informative and many papers flirt with the hagiographic account. Sergio Mattos published the most complete and elaborated biography to date but not from "a critical perspective" (2014, p.20) as he intended, according to our opinion. With many anecdotal passages, his account is limited to "identifying the man behind the work", as he recognized at the end of the book (2014, p.302).

In less laudatory terms, Giovandro Ferreira (2013) advanced analysis further; he was responsible for a formal examination of Marques de Melo's contributions to content analysis studies in Brazil. Despite his reflexive intentions, Jorge Pedro Sousa did not go beyond the record of development stages and the detailed description of Marques de Melo's work (Sousa, 2010, 2018). Considering this and having exhausted the historiographic record, we intend to change the focus for academic reception assuming an attitude that is both critical and analytical. Our aim here is to elaborate a historicalhermeneutical judgment on the form and limits of his ideas.

Going beyond the examination of their empirical-analytical coherence defended by the positivist philosophy of science, Jürgen Habermas (1983) advocates that, submitted to historicalhermeneutical analysis, theories can be: a) restored, that is, presented again according to their original sources; b) revised, that is, updated in order to cope with new circumstances; and c) rebuilt, that is, reordered to continue fulfilling their tasks without prejudice. Marques de Melo did not propose to present and, therefore, did not leave us with a finished journalism theory; even if there is no overarching theory, this, however, does not mean that a journalistic thinking cannot be discovered or revealed, that is, extracted and systematized rationally from his work, as has already been done, for example, with Max Weber's essays by Roth e Schluchter (1979) or Mommsen (1981).

Methodologically it means that our article is neither a discourse analysis nor a systematization of information, but a historical-reflexive hermeneutic on his work supported by the theories of Jürgen Habermas and Paul Ricœur (see also Goldmann, 
1969). In this sense, our starting point is the notion of work, as defined by the French thinker. According to him, an intellectual work would be a totality formed by collections of texts to which an authorship is attributed or recognized (Ricœur, 1977, p.49). To apprehend it means to capture the relationship between a subject, a situation and a project supposedly proposed in a collection of texts. For this, the focus of our study does not concern the subject itself, because it would be a psychological study; at the same time, it does not concern the situation, because it would be a sociological study.

Assuming the first as a reference and the second as an interference factor, our task consists mainly of examining the content and questioning the scope of the theoretical proposals contained in the text, from a point of view that analyzes and diagnoses it as a project in a given trajectory. "The work creates an audience for itself", insofar as it is detached from its author and the original context: this release from both is a "fundamental condition for the recognition of a critical instance within the interpretation [proposed by the scholar]", says Ricœur (1977, p.136). For this reason, he adds, "we no longer define hermeneutics in terms of the search for a person and its psychological intentions, which would be concealed behind the text", nor by the "dismantling of the [objective] structures of the text" (Ricœur, 1977, p.56). Instead, it is defined by an analysis of its more or less global historical meaning assuming a point of view and a distance that emerge between the creation of the work and its reception by the interpreter (Ricœur, 1977, pp. 43-59).

It is worth considering that this appropriation is not purely historicist, a simple report, since it aims to criticize, "to take position in relation to the work", "judging it affirmative or negatively" in relation to the circumstances that have determined its trajectory during the period of time considered in the research (Habermas, 1987, pp. 8697). Although the nature of the object prevents complete proof and maintains the evaluation in the sphere of the rationally documented hypothesis, there is nothing impeding the study of arguments and motives contained in the examined work. It is important to analyze whether they are still historically and epistemologically grounded, after a period of time since the first proposition.

Revealing an academic thought the intellectual value of which is apparent for those interested in journalism theory, this article aims to arouse curiosity and, perhaps, reflection on a topic of potential interest to many scholars in the academic community. At the same 
time, we are aware that, emerging from the debate, the conclusions presented in this article can be hampered by the ignorance of some documents, as well as by errors of reasoning and evaluation (see Habermas, 1983, pp. 258-261).

Marques de Melo was formed intellectually in the post-war period, in a context more or less equally linked to the democratic renewal of Brazilian liberal thought and the national-developmentalist doctrine that appeared in several countries in Latin America. Based on this and other premises, we believe it is possible to reveal and expose with some intrinsic organization, if not a theory, at least singular and authorial thinking. The hypothesis is that there is even if incomplete - a political doctrine, a variant of Brazilian liberal thought underlying his analyzes.

An introducer of descriptive content analysis in the early 1970s (Marques de Melo, 1972; Ferreira, 2013), Marques de Melo grew in renown by studying journalistic genres (Marques de Melo, 1985, 1992). We will argue that, instead, his work matters because it was an expression of the contradictions of Brazilian democraticdevelopmentalist liberalism with the national reality. For us, his "historiographical turn" was an effect of the impasse that, putting aside its intrinsic merits, led his journalistic thinking to be out of tune with national life.

\section{Fundamentals of José Marques de Melo's press theory}

Another pioneer of journalism research in Brazil (Vizeu, 2007; Brito, 2018), Luiz Beltrão (1918-1986), supported José Marques de Melo's entry into the academic field and, in part, influenced his career during his first years. Most important in this, however, was the Latin American assimilation of communication research originating in the United States, and learned by him in Ciespal. As Luiz Beltrão, Marques de Melo became a politicized agent from the liberal tradition of intellectuals who had graduated in law with a Catholic profile ${ }^{3}$. Notwithstanding, his specific academic formation was influenced in the 1960s by diffusionist concepts and developmentalist theories put into circulation by the media and journalism center open in Ecuador.

Marques de Melo returned from a postgraduate exchange there not only converted to the creed of North American communication research, but convinced that the solution to Brazilian 
problems, with which he had been concerned since a young age, as a Communist Party sympathizer and a militant of Catholic social action, would be obtained through the use of the press and other means of information in favor of what had come to be called "economic and social development" (Furtado, 1964; Jaguaribe, 1962; Bresser-Pereira, 1984). "As a citizen, I never hesitated to frankly defend what I wanted for my society and for my people. All of this is contained in the books I wrote", he said as a profession of faith in 2003 (Marques de Melo, 2005a, p.121).

Leaving this broader issue aside for reasons of space here (Peruzzo, 2014, pp. 175-188), it is important to note how much this doctrine has influenced his theorizing on journalism. After the 1930 Revolution, there was, in Brazil, a process of substituting manufactured imports that promoted economic and social progress in the largest cities. Proceeding with the synthesis between the liberal doctrine from the 19th century and the developmentalist thought that emerged in the 1950s, Marques de Melo outlined, in Brazil, a national variant of the doctrine of social responsibility with which, in the United States, the excesses of liberalism had been supposedly corrected (Peterson, 1956, pp. 73-102).

From the beginning, his work was stimulated with a thesis derived from his idol, Ruy Barbosa, a Brazilian jurist, publicist, politician and diplomat at the turn to the $20^{\text {th }}$ century. He used to say that "when the force of the press emerges in democratic societies, establishing the mediation of newspapers and journalists in relation to the exercise of powers constituted, the metaphor of the fourth power is created, legitimizing the surveillance the government apparatus by civil society" (Marques de Melo, 2004a, p.11). At same time, Marques de Melo thought about journalism in the context of the Brazilian experience, based on the fact that, despite its development, it is still a country marked by economic marginality of the majority of the population. It was with this approach that he intervened in the reavaluation of Brazilian development theory which emerged in the 1970s (Santos, 2000).

Until the Estado Novo dictatorship (1937-1945), journalism served in Brazil as a free forum for the dissemination of political flags and the defense of national causes preached by literati constituted hegemonically by bachelors in law (Adorno, pp.157-234; Miceli, 1979; Capelato, 1989). Having graduated in law from the Federal University of Pernambuco, Marques de Melo adapted and followed this 
intellectual model in his career, derived from the oligarchic liberalism of Brazil's imperial era (Nogueira, 1984), amid the situation created through the process of the industrialization of economic activity and democratization of institutional structures post-1945 (Paim, 1984).

Drawing inspiration from Ruy Barbosa's and Barbosa Lima Sobrinho's ideas (Marques de Melo, 2012a, p.197), he was influenced and uncritically adopted the liberal theory of press (Marques de Melo, 1965). It must also be said that he assimilated the idea of the right to information (Marques de Melo, 1986), as presented by the Church's social doctrine (Marques de Melo, 1981b) ${ }^{4}$. However, he qualified as a distinguished thinker on the subject only because, unlike others, he was able to combine these influences into an original synthesis which benefited from an appropriation from Ciespal theorists' developmental doctrine of the 1960s.

Before and after him, other Brazilian authors theorized about journalism with essays and treaties of a generic nature, without paying attention to local particularities and historical circumstances. Instead of this, Marques de Melo thought mainly of its meaning and situation in Brazil, aiming to contribute to its academic legitimation as an autonomous study area with a liberal-developmentalist lens. He experienced and tried to think about the transition from the bohemian and romantic to professional journalism, aiming to form and inform public opinion in a more technical way. He underwrote the thesis according to which "people's economic and social development is largely subject to the careful guidance provided to them by men who have the resources at hand to disseminate facts and ideas" (Ammirato, 1963, p.59; Marques de Melo, 1965).

Apart from a brief period around 1970, when he came to flirt with the nationalist thesis that the Brazilian press would be a subjugated force of alien interests (Rabelo, 1966; Marques de Melo, $1971,1976)$ and later, in the early 1980s, when he helped to spread the New International Information Order creed (Matta, 1980; Beltrán \& Cardona, 1982; Marques de Melo, 1985), Marques de Melo always avoided the scapegoat theory of the press, blaming foreign forces for its faults. He preferred to think about it from a perspective that was intentionally Brazilian and Latin American.

The author's sympathies for the Christian Church's social action doctrine only partially reduced his middle-class intellectual interest in thinking and changing the country within the liberal framework. Believing that journalism must be thought out from the 
context of journalism itself (Sousa, 2010, p.56), Marques de Melo prevented himself from seeing the extent to which his own ideas about the matter went beyond that milestone. Even worse, he maintained a personal belief that, admirably from an ethical point of view, prevented him from seeing the limits of liberalism in a country with the history that Brazil has (Schwarz, 1992, 1999; Ricúpero, 2013).

Underlying his views on journalism, we discover a confrontation with the paradoxical fact that, in Brazil, economic development has revealed itself as unable to eradicate poverty and establish full citizenship. The country's huge number of socially and economically excluded people shows that a political order guided by social justice is not yet a reality. Marques de Melo preferred to defend the need for national development, instead of to do an analysis of its challenges (Marques de Melo, 2011).

A liberal democrat with a Christian inclination, for whom it was ever important to be "envaluing the press as a means of disseminating Catholic ideas" (Marques de Melo, 2004b, p. 16 - see below, note 5), he defended the idea, throughout his career, that the Brazilian teaching of journalism should:

go beyond a caricature from the time of Balzac that has led us to favor the aristocratic training of journalists committed to the interests of educated or moderately educate elites. We need to devise discursive strategies in line with the repertoire of under-informed population and apply tactics that motivate the cultural appetite for the press among those marginalized from the consumer society. (Marques de Melo, 2012a, p.136).

This means historically and analytically that, in his work, journalism is seen as a point of convergence between communication and development, a form without which there is no way to achieve full citizenship in Brazil. According to the author, the role of journalism is to guide the citizen in making decisions that "reverberate their full participation in society" (Marques de Melo, 1971, p.78). Journalism is a universal phenomenon which originated in Europe but the development of which in Brazilian lands experienced circumstances that changed its operational standards. There journalism received relatively original characteristics:

We have a journalism that is morphologically distant from Portuguese standards, but that also does not constitute a copy of French and North American models [...] Brazilian journalism has been creatively structured, acquired a differentiated characteristic, selectively absorbing the models that were insinuated or imposed over the country. (Marques de Melo, 1985, p.132). 
Despite technological advances, professional improvements in business organization, and the achievement of freedom for the press after 1984, the country has not seen the transformation of journalism into an agent for national development. In general, information has continued to be "the privilege of national elites" (Marques de Melo, 2003, p.147). Poor people have not become citizens, that is, they have not benefited from press freedom and progress in journalism as other groups did. "Marginalized from literate culture, they do not participate equally in the opportunities for social advancement that democratic society offers them" (p.157).

Having seen from afar the situation that arises with the new media, supported by the transnational private economic power, Marques de Melo recognized "the effort governments have been making to expand the frontiers of the information society in national territory" (Marques de Melo, 2012a, p.157). In spite of the fact that electronic communication ended with "media exclusion" he, however, does not change his belief that:

\footnotetext{
The large contingents of our population remain outside constitutional freedom. They are failing to enjoy both the prerogative of free expression and the right to access information that would enable them to have full citizenship and, consequently, to participate fully in democratic life. (Marques de Melo, 2003, p.147).
}

A victim of a mixture of ideological blindness and desiring discourse, Marques de Melo abstractly projected in the country the experience of an educated middle class of whom he was a spokesman, without noticing that this social group tends to disappear within the leveling tendencies of the so-called new capitalism (Sennett, 2006; Guerra, 2006; Porchmann, 2015). Adopting an abstract and essentially academic worldview, he was unable to perceive the perverse effects of the conjunction between an oligarchic power system and the associated capitalism model existing in Brazil (Faoro, 1975; Schwartzman, 2003). He placed, on the shoulders of the national educational system, the task of developing citizenship in society, and, on the shoulders of the press, the function of informing citizens to support the exercise of public power in a democratic context. 


\section{Problems of liberal-developmentalist historicism}

From all that has been said, we can verify without surprise that, for him, journalism is paradoxically a negative greatness. It is a promise that is continually postponed, much more than a really transforming force, operating in social praxis. Marques de Melo arbitrarily gave journalism a mission: to encourage national development and, at the same time, guarantee citizens' right to information. However, he continued to argue, throughout his career, that the condition of journalism in Brazil is, in essence, that of an institution permanently backwarded in historical and sociological terms.

Progressively classificatory in his procedures, Marques de Melo hermeneutically founded his journalistic analysis in a historicism with a political-sociological bias concerning its epistemological background. His first major work was his doctoral thesis defended in 1973, republished with the title História Social da imprensa in 2003. In summary, this work aims to point out the socio-cultural factors that caused the delay in the appearance of the press in Brazil (1808). Seemingly simple, the objective hides a huge epistemological problem. "Admitting as a basic premise that there was a delay [...] in the implantation of the press in Brazilian society" (Marques de Melo, 1973, p.110), the author creates a fact that did not exist for contemporaries of that time.

Marques de Melo inherited uncritically from scholars who preceded him, as Werneck Sodré ([1966] 1998, pp. 19-33) for example, the a-historical postulation that there was a delay in the development of the press to, paradoxically, argue that this delay is the main cause of journalism's permanent underdevelopment in Brazil. Opposing linearly past and future, backwardness and progress, he not only suggested a hierarchy in which modern journalism was a paradigm of analysis, he also blamed the institution's intrinsic underdevelopment for its failure as an activity supposedly intended to collaborate for the country's redemption.

Unless we find documentary evidence to prove the contrary, the delay in the development of the Brazilian press is a post factum political-fictional construction, since it did not exist or was perceived for anyone at least until 1808, year of its introduction in the country. This means that the author subordinated his journalism theory to a historicist scheme of a liberal-developmentalist nature, in which the modern business press would be a consummation or terminal destiny of what, in the same period, the academy had begun to call the communication process. 
For this, the central point in the argument declaring the lateness of press development in Brazil is not historiographical but political-doctrinal. It hides the philosophy of history that guides the hermeneutics of the press proposed by the author.

The obstacles faced by the premature appearance of the press in the old Portuguese colony are the same that will preclude the growth of editorial and journalistic activities in independent Brazil (Marques de Melo, 1973, p.19, emphasis added).

Karl Popper wrote about historicism as a misery of thinking (Popper, 1960). Although, for us, this is not always the case, we believe that this is a recurring problem in Marques de Melo's work: he was prisoner of a misery of historicism. Subjecting the concrete process to an inflexible doctrine, his analysis did not understand journalism as an action influenced by interests in conflicts in certain situations. He tried to decide its trajectory theoretically, approaching the topic from a linear and monotonous perspective, until the end:

The sociocultural deficiencies that made the press an institution without an effective function in the structure of colonial society are exactly the same as those that remain unchanged in the poorest parts of the national territory or that developed slowly, supporting the lag or rickets of our experiences of printed communication. (Marques de Melo, 2005a, p.73).

Ignoring the relations of the press with the national oligarchic system and the problems imposed on it by its dependence from the capitalist entrepreneurial initiative, Marques de Melo tried to believe that the market economy and professional training would allow journalism to overcome the national atavism of bad information. He was not able to examine these processes in a richer way, seeing his deplorable situation as a kind of "endemic evil", a historical aberration inscribed in national life only.

Marques de Melo observed well and very early that, in Brazil, given the precariousness of public education, the professional press acts only among opinion-forming circles (Marques de Melo, 1971, p.102). In the absence of deeper and more specific reflection, however, he did not go beyond abstract preaching in favor of education and the appeal to the elites' civic conscience when facing the problem. Marques de Melo defined as functional anomaly the fact that the market is restricted to the elite, that is, the "sector that benefits from national progress", the "small population that benefits from the development model", which limited journalism in 
its opinion and information functions, that is, as an economic and political development factor (p.76).

Overburdened by an epistemological illusion, he argued that the press should be explained by itself only, without seeing that this vision was sustained in a liberal hermeneutic aliened to the reality of his country. He despised the negative impact of the oligarchic power system in the development of capitalism and never considered explaining the situation of the Brazilian press through the citizenship restrictions created by centuries of slavery. He identified himself abstractly with the market forces and private entrepreneurial interests, blocking the paths to analyze the political commitments that, until now, prevent them to endorse a project capable of integrating the large mass of the population into the citizenship.

Despite observing the moments when journalism sparked political reform movements, intervening critically against the current power system, Marques de Melo did not go beyond the abstract preaching on economic and social progress towards the enlargement of the market as a way to develop journalism, established early on, in his criticism of Alberto Dines' ideas (Marques de Melo, 1971).

Stuck in his aporias, the author ended his career without seeing the inclusion of popular sectors in the process of forming citizenship through the press, and according to our judgment, he was unable to adequately diagnose the impediments that made the process incomplete. Unable to explain "the symptoms of exhaustion" of traditional journalism in transition to new media (Marques de Melo, 2006a, p. vi), he began to nurture abstract hope in a redemption that, in his opinion, perhaps could come from entertainment.

This may mean that, in the end, Marques de Melo was involuntarily approaching postmodernism, admitting that entertainment, contrary to what he initially thought, is not a social anesthetic (Marques de Melo, 1981 a), but a means destined to fill "the lack of journalism for the mass and not for the elites" in a country like Brazil (Marques de Melo, 2005a, p.60).

\section{Journalism theory}

Structuring his work according to the idea of absence: absence of development in the periodical press, circumscribed to the "minority slice of society" (Marques de Melo, 2012a, p.156), but 
also absence of serious and responsible journalism, Marques de Melo did not stand out for analyzing the concrete manifestations of the phenomenon, much less for examining its objective contradictions. With regard to journalism, he stood out mainly as a doctrinaire and memorialist. Seeing journalism as a public law activity ensured by private entrepreneurship in a democratic environment, his merits, in terms of empirical research, were notably in the field of morphological content analysis only (Marques de Melo, 1972).

Marques de Melo developed a thesis of which he became a prisoner. Through a Durkheimian approach, he postulated that the press is a functional institution of any modern society whose delays must be overcome in order to support the progress of national political life. For him, this phenomenon has an emancipatory potential that needs to be unlocked by improving the educational system as a whole, including through journalistic training. But he did not examine this subject, limiting himself to speculations about Paulo Freire's work.

Although he claims that the press alone does not have the power to change reality and can, at most, accelerate changes when society is ready to unleash them, Marques de Melo defended a conversion of newspapers into "socially useful instruments for the readers", in order to "solve the functional atrophy that characterizes them for a long time" (Marques de Melo, 1971, p.77). Even so he did not clarify how this could happen in a country marked by a large marginalized population, with low purchasing power, poor educational skills and regional inequalities (p. 81).

Marques de Melo lived without knowing about and without subjecting to critical reflection the dilemma that involves attributing to the press a positive influence on national development that this development, in turn, restricts. Avoiding analyzing the contradictions and synergies between dependent capitalism and cultural industry, the deleterious effects of the oligarchic system in the operationalization of government policies, the author let himself be carried away by a "mystique" (Marques de Melo, 2011, p.135) of a mythical development that would magically "push Brazil towards modernity" (Marques de Melo, 1991a, p.7).

Working with the worst theses from the theories of economic and social development, Marques de Melo ignored the fact that development and underdevelopment must be considered as two ideological aspects of the same process. And that this is less about 
creation and diffusion of modern technology (Furtado, 1964) than about contradictions and conflicts present in capitalism - a key factor, although poorly diagnosed by Marques Melo, in the historical development of Brazil.

A champion of a civil society to come, he defended the need to fight for the right to information and education, because without it there would be no citizenship interested in discovering what determines and may be useful in its existence (Marques de Melo, 1986, pp. 65-82). From the beginning, he placed on the shoulders of the press and school, preferably owned by the private sector, responsibility for social change, political education and citizenship integration (Marques de Melo, 1971). Since "there is no way to develop communication without having economic development", an understanding he assimilated from Ciespal (Marques de Melo, 2018, p.180), he placed the mission of overcoming "the anachronism of institutions that constitute our society" (Marques de Melo, 2011, p.42), the press included, in the hands of the market.

Marques de Melo did not go beyond the moral objection when, very vaguely, he made the accusation that there was alienating, anesthetizing contents, as he used to say, in the national press. He never saw this as an expression of the fact that news is a commodity, which needs to meet consumer demands in a capitalist society. Betting on business competition and the pluralism of supply as ways to offer the best sources of information, he also thought that those anomalies would be gradually corrected with the improvement of journalists' professional training.

Despite his critical essays written at the final period of the military dictatorship (1980-1985), Marques de Melo ended up reiterating the thesis he defended at the beginning: newspapers are "vehicles for the dissemination of reliable information, selected with basis on its intrinsic social value and the ethical opinion of newspaper" (Marques de Melo, 1971, p.77). Ultimately, his view was that "the essential function of the journalist is to truthfully inform what happens but also express opinions that contribute to unveiling the social scenarios" (Marques de Melo, 2005a, p.71).

Influenced by Otto Groth's theory, he argued, in a contradictory way, that the journalist is "a social mediator, able to report the relevant events of society, eventually valuing them, to allow citizens to make their daily decisions and form their own points of view" (Marques de Melo, 2005a, p.71), because his final position was that journalists 
"form public opinion, since they disseminate simplified knowledge about everyday life and lead opinion leaders in primary groups to take a position about the direction of society" (p. 71).

Marques de Melo followed his master and recycled, with the term communication, the older Beltranian understanding according to which journalism is a social function whose origins date back to prehistory (Beltrão, [1964] 2006). Underlying his analyses, there was a progressive and liberal anthropology articulated in an epistemologically functionalist key. For him, journalism responds to the "passive need that all individuals have to be in harmony with environment" at the same time that providing information, "plays an active role in the life of society". Regardless of the vehicle, news "relies on the socio-psychological process that maintains united an intimate and permanently connected community to complex institutions that seek to meet its expectations of cognitive updating about life in society" (Marques de Melo, 1991b, p.21, 2012a, p.180).

This means that "with human curiosity as a nutrient, journalism is anchored in the desire to know what happens in environment, configuring a phenomenon characterized sociologically as a materialization of the 'social need for information'" (Marques de Melo, 2012a, p.166).

While living in self-sufficient, closed communities, human beings directly exercised the ability to know what was going on around. From the moment they expanded their cognitive horizons, interacting at a distance, however, citizens began to demand reports capable of supporting their daily decisions. (Marques de Melo, 2012a, p.166, 1991b, p.21).

Always on the verge of intellectual confusion for his open profession of faith in theoretical eclecticism, Marques de Melo contested the doctrine of objectivity from the North American school, without denying its property at all, because, for him, the essence of journalism is information, relativizing the opinionist doctrine from the European school that determined the evolution of journalism in Brazil until the 1950s at least (Marques de Melo, 1985). During his period of radicalism, he spoke negatively of journalism as an activity that depoliticizes itself as "concepts of objectivity, neutrality and impartiality emerge" (Marques de Melo, 1986, p.40). All these notions are a myth, "an idea that the American news factories wanted to impose on the whole world" (Marques de Melo, 1986, p.57), since in a liberal and democratic capitalist society there are always different points of view about what is really happening. 
On the other hand, this should not be used as a license to affirm that "the journalistic message is necessarily politicized, in persuasive and instrumentalizing terms, as do so many wrong exegetes of Marx" (Marques de Melo, 1986, p.57). Journalism has enough autonomy to admit "coexistence and permanent confrontation between different ways of appropriate and reporting reality" (p.58). Although journalism is only able to provide versions of facts and opinions about them (pp. 95-107), it "does not exclude the true reproduction of events [within these limits], whatever the orientation of the newspaper or its professionals" (p.58).

Resuming the thesis defended in his first publication (Marques de Melo, 1965), the following passage, expressed in his last years, is very clear in this sense:

\begin{abstract}
[The journalist] must keep in mind the duty to respect the truth. I think today's generation often embarks on the vessels of postmodernism, where it is said that everything is communication and nothing is journalism, and with this they end up getting lost. I don't see the matter that way, I think that in fact journalism is an activity that presupposes the observation of reality and that this reality must be truly reported. I am not saying impartially, because there is no impartial journalism, but there is true journalism, in the sense that it shows that facts have multiple dimensions. Journalists must show all sides of the news, of facts, of events, and let the reader take his own position, the viewer takes a position. When the journalist tries to inflict his point of view on a certain fact, he is going from being a journalist to being an advertiser, a propagandist. (Marques de Melo, 2008 as cited in Mattos, 2014, pp. 256-257).
\end{abstract}

For the author, there is no doubt that entrepreneurial interests guide the subjects and exercise control over what will be said by the newspapers but there is not too "about the possibilities professionals have to intervene in this control". Information that reaches the public "is [the] product of a negotiation between the parts" (Marques de Melo, 1985, pp. 59-60). Flirting with sociologism typical of the period, he stated in his most radical phase that there are "the bourgeois press and the press of the subordinate classes" "each one spreading his worldview" (Marques de Melo, 1985, p.41). At the same time, however, he saw that "the veracity [of information] is [a] consequence of the availability of journalistic sources that allow the community to confront facts and their versions" (p.58). Only when they are lacking do we have "the monopoly of the press [...] enjoyed by the bourgeoisie" (p.82) - which implies that, in this extreme situation, only "freedom of the press and the free market are nothing more than myths in capitalist society" (p.41). 
Even so, Marques de Melo never thought about a political and social revolution to put an end to this eventual situation. A radical democrat and not a socialist, he ever postulated the extension of the principle of the right to information, instead of state control of the media. After he defined himself in the mid-1980s as a "left-wing person" and a "Christian", he revised or clarified the first characterization, declaring himself "progressive" in the end (Matos, 2014, p.27 and p.255). In his books, he never thought that the problems of national press and the small influence of serious journalism on the formation of citizenship in comparison with sensationalism, for example, originated from the historical premises on which Brazilian capitalism developed.

When he contested the fact that, in our country, freedom of the press and the right to information are "the privilege of minorities", if not a "political strategy intending the ideological control of society" (Marques de Melo, 1984, p.99), it was not to accuse the economic and political system but to call the business community and the ruling class to their responsibilities. Marques de Melo wanted a press committed "to the creation of a new society, more equal, more fraternal and, therefore, more Christian" (Marques de Melo, 1985, p.59), assuming that this could come from a changing of consciousness and an improvement in education, a combined process whose circumstances and limits he never analyzed.

Despite continuing to reaffirm the conclusion extracted from his thesis (Marques de Melo, 1973) - i.e., that the problems of journalism "can only be fully understood if located within the structural limitations of our economic development", since "dependent capitalism embedded in the country failed to reproduce the conditions that marked the press evolution in the pioneering areas of industrialization" -, he resisted from drawing the due consequences. For him, the obstacles concerning press development in the country were, for Brazil: a) the low purchasing power of the Brazilian people; b) the chronic illiteracy; c) the absence of mass citizenship; and d) the press elitism, which suppressed the "themes and desires of the subordinate classes"; he felt that these would be overcome with more education, professionalism, and business action (Marques de Melo, 2006, pp. 87-88, 1985).

Appealing to a practically mythical "delay" that would follow the press throughout its history in Brazil, Marques de Melo ideologically prevented himself from continuing to analyze the reasons why journalistic information has always been a "privilege of 
the ruling class", as he recognized (Marques de Melo, 2006, p.131). The "economic socialization" we can see in his work is that proposed by the market and business activity, because according to him, there is no other way to "remove the majority of our population from the current conditions of hunger and misery, of integrating people into national life to participate fully in society" (p.132).

The solution vaguely defended in his thesis to solve these problems, including the underdevelopment of the process of formation and information of citizenship, would be more capitalism. Without economic development guided by private initiative with complementary action in education by the State, there is no way to make journalism viable in its information and opinion functions (Marques de Melo, 1971, p. 77), and to socially assure the right to information without which citizenship does not develop anywhere (Marques de Melo, 1986, 1971, p.78).

There was, in Marques de Melo's thought, the liberal belief that the well-trained journalist can help to break the atomism, "to overcome the uncommunication stage in which the people live, in virtue of isolation from decision-making centers or the conformity imposed by mass media, skillfully manipulated by the dominant class" (Marques de Melo, [1985] 2006, p.132). For him, the objective was always to "neutralize" these problems, wagering on a democratic radicalization of bourgeois democracy and an expansion of the liberal public - "[cap]able of confirming (each version) by comparing with others" (Marques de Melo, 1986, p.105), through creation of a free and responsible press managed by the private sector. State control over the means of information, much less its instrumentalization in the class struggle, has never been part of his intellectual agenda, as many of his contemporaries thought was the case.

\section{Conclusion}

After the 1930 Revolution, Brazil, like other countries on the periphery of the capitalist world order, witnessed the emergence of a series of economic actions and the activation of public policies that, over time and in the midst of conflicts with other projects, were institutionalized to the point of defining what came to be called developmentalism, under the impact of the United Nations Economic Commission for Latin America and the Caribbean proposals. 
Hegemonic in the Juscelino Kubitschek government (19561959), development theory, for its defenders, meant economic progress coordinated by the state, contrary to the sense given by nationalist currents that, in its left-wing (socialist) variant, saw underdevelopment as the consequence of external economic domination, and in the right-wing (neoliberal) variant, believed that economic backwardness would be overcome by opening markets to foreign investment (Mendonça, 1986).

Engaged in this process, José Marques de Melo positioned himself in the field of journalism studies as a defender of democracy as a universal value and theorist of what we will call here liberal developmentalism (Sallum Jr., 2013). Inclined to see the market economy as the best basis for national political and economic development, he was essentially an anti-authoritarian, defending freedom of initiative and expression. Marques de Melo wanted to see communication from a perspective that, rejecting nationalism as much as statism, would favor economic liberalism at the same time as, encouraged and planned by the State, it opened to democratic participation, because:

\begin{abstract}
When a society preserves the right of expression of its elites and, at the same time, guarantees the right to information to all its citizens, it is strengthening its democratic experience and preventing itself from constitutional setbacks. Only a wellinformed nation is able to choose governments capable of converting press freedom into an essential piece of permanent democratic improvement. (Marques de Melo, 2005c, p. 244).
\end{abstract}

According to José Guilherme Merquior (1991), we can distinguish three forms of liberalism: the classical (constitutional state based on the organization of civil society + free economic initiative), the social (encouraging the democratization of individual freedoms + mechanisms for social and economic protection) and the neoliberal (moral conservatism + competitive individualism + minimal state). Marques de Melo abstractly rejected the characteristics of the latter model, since he postulated the implementation of a mix of the first two, adding to it the social doctrine from the Christian Church (Marques de Melo, $1981 \mathrm{~b})^{5}$.

Ignoring in his analysis the contradictions in the country's historical development, the systematic reproduction of socioeconomic marginality, and the oligarchic character of political institutions in Brazil, he advocated that the solution for national problems would be the result of progress in education commanded by the public power. And that with regard to journalism, it would be the development of 
free initiative and preparation for professional practice. The condition for the independence of journalism and information has always been, in his view, to keep organizations "functioning within the principles of the market economy" (Marques de Melo, 2005a, p.72).

Marques de Melo had a long career without intending to transcend the premises that marked his beginning, relying metaphysically on a naive anthropology, derived from a liberal ideology out of step with the national experience. Sensitive to the left-wing radicalization that emerged among the intellectual groups in contact with the Catholic Church, the author radicalized his liberaldevelopmentalist agenda for a time, exploring the conflict paradigm during the 1980s. Ultimately, however, there was little or no change in his way of thinking about journalism.

Only in his final years and in a very timid way, did he begin to examine the case of digital journalism and to analyze the demand to overcome the old doctrines that, transforming social life, were imposing new objective contradictions on journalism. Marques de Melo analyzed with difficulty the impact of digital media on this institution, and how it has helped to maintain the underdevelopment of the Gutenberg Galaxy in Brazil. He never decided if it was better to celebrate the success of the new media business, to criticize the politically anesthetic meaning of the new forms of journalism, or just write a chronicle about this situation.

Seeing journalism as a private institution responsible for ensuring civil rights in democracy, he moved from defending national interests in the media, supposedly threatened by foreign influence in the early 1970s, to a position favorable to the establishment of an egalitarian exchange with other economic powers since the late 1980s. Defender of "development with social justice" (Marques de Melo, 2011 , p.11) and of "democracy as a universal value" (Marques de Melo, 1986), he attributed to education and the press the ability to overcome the exclusionary social system that he denied to political and social revolution. For him, Brazilian journalism would have in its entrepreneurial essence the means to overcome the adversities created by a history marked by an exclusive economic system and the exercise of oligarchic power that he notwithstanding could not thinking about, opting to place the blame for national problems on a mythical underdevelopment of institutions.

Involved in his own ideological aporias, Marques de Melo continued, until his final years, without seeing, as he expected, the 
inclusion of popular sectors in the process of forming citizenship through the press. Unable to explain "the exhaustion symptoms" of traditional journalism in transition to the new media (Marques de Melo, 2006a, p.6), he pathetically cogitated on whether the renewal of journalism would not come from entertainment (Marques de Melo, 2005, p.60).

Loosely and naively supported by functionalist doctrines from the early 20th century, his status as an educated middle-class man and a reformist intellectual dissatisfied with the national reality made him think of the press and journalism as a necessary and notwithstanding socially and economically absent solution for the development of capitalism in Brazil.

Marques de Melo simultaneously undervalued and overvalued himself saying that his "role in the Latin American academic scene [was] much more of a critical historian than of a paradigmatic protagonist" (Marques de Melo, 2005a, p.149). He overvalued himself because his historiographic work never went beyond the collection, ordering and classification of information. And he underestimated himself because, despite the epistemological deficits, his work succeeded in constituting a unique and original reflective moment in Brazilian journalistic thinking.

An unrecognized exponent of a minority and still little studied perspective of Brazilian liberalism, Marques de Melo had his theoretical reflection on journalism clouded by utopia, since it was disconnected from the country's historical formation. Until the end, he maintained a naive creed in the saving power of a free, plural and accessible press for all people, forbidding himself from thinking properly about the characteristics, interventions and problems of journalism in Brazil. He ideologically predetermined the essence and meaning of the activity in an intellectual framework in which the examination of national reality was rejected in favor of its subjection to a theory of a doctrinal nature.

An idealistic historian in the sense of ignoring the way ideas are inscribed in praxis, he presented a view of the press based on indignation and goodwill, without being critical and unable to reflect enough on the limits of the development of liberalism in Brazil.

Judging his intellectual work requires considering his greatness as a pioneer in the field and his tragedy as an academic with no major echo in Brazilian journalism studies. 
1 Emerging from the late 1940s, the areas of journalism, advertising, cinema, television, etc. were academically autonomous at the Brazilian university until 1969, when they became part of the new field of communication studies by official act. After the creation of Brazilian Association of Researchers in Journalism in 2003, Marques de Melo led the movement responsible for the separation of journalism from that field, which occurred in 2012 (Meditsch, 2012). In his view, although journalism theory and research are part of communication studies, they form a separate project, with its own history and identity (Marques de Melo, $2012 b)$.

2 Considering the history of journalistic thinking in Brazil, Marques de Melo would form a group with Alberto Dines (1974), for example.

3 It would be important to consider in this context that, unfit for engineering, Marques de Melo followed his father's recommendation to graduate in law at a university recognized for cultivating a liberal attitude, without giving up the desire to graduate in journalism at a Catholic university (Marques de Melo, 2015). And that, "initiator of the formation of a critical spirit in the Brazilian intellectuality" (Paim, 1984, pp. 380-381), the Faculty of Law of Recife had, at its peak, the ambition of "forming a nation through science" (Bonet, 2004, p. 41).

4 Son of a small liberal businessman, Marques de Melo came from the rural middle class in northeastern Brazil, having learned to be Catholic with his mother and aunts. He studied at a confessional school and joined the Catholic Youth (Matos, 2014, pp. 106-107; Marques de Melo, 2018, p.170). A sympathizer of the Church's social doctrine, he worked in São Paulo very close to the Archdiocese (see below, note 5) and always obtained support from Vozes, Loyola, Paulus and Paulinas, the main confessional publishers in Brazil. Author of many works in the field, Marques de Melo was also supervisor of theses and dissertations on Christian social communication. Unless better information is available, it seems that his work has not yet been studied from this angle, only indirectly linked to his journalistic thinking (Marques de Melo, 1981b).

5 Supported by the Archdiocese of São Paulo leaders and following the determinations of the Second Vatican Council (1961), Marques de Melo intervened decisively, from the 
end of the 1960s, in the process of adapting the Catholic Church to the changes in the way of life that occurred in the last century (Marques de Melo, 2004b, p.16). As a member of the committee responsible for the creation of the Brazilian Christian Union of Social Communication in 1969, he assumed its presidency from 1974-1975 (Matos, 2014, pp. 203206) and, over the years, campaigned for the renewal of Christian ideas in Brazil, preaching the development of new communication practices (Stollmeier, 1996; Gomes, 2003). Seeing this as a "democratizing improvement", he worked for "ecclesial authorities become true aspiration's interpreters of the communities in which they intervene, in order to exercise a power compatible with the essence of [Christian] community life" (Marques de Melo, 2005b, p. 30).

REFERENCES: JOSÉ MARQUES DE MELO

The author's works and other materials are ordered according to the date of publication (most recently or most recently), in order to facilitate the reader's consultation.

Marques de Melo, J., \& Tufte, T. (2018). A comunicação serve para que? [What Communication is for?] Intercom: Revista Brasileira de Ciências da Comunicação, 41 (2), 169-185. DOI: 10.1590/180958442018210

Marques de Melo, J. (2015, feb. 26). Memória Intercom. Portal Intercom. http://portalintercom.org.br/memoria/depoimentos/josemarques-de-melo/entrevista

Marques de Melo, J. (2012a). História do jornalismo: Itinerário crítico, mosaico contextual [History of journalism: critical itinerary, contextual mosaic]. São Paulo: Paulus.

Marques de Melo, J. (2012b). A prima pobre das ciências sociais [The poor cousin from the social sciences]. Pesquisa FAPESP. https:// revistapesquisa.fapesp.br/jose-marques-de-melo-a-prima-pobre-dasciencias-sociais/

Marques de Melo, J. (2011). Brasil democrático: comunicação $e$ desenvolvimento [Democratic Brazil: communication and development]. Brasília: IPEA.

Marques de Melo, J., \& Vizia, B. (2010, nov. 19). Falta uma pesquisa 
em Comunicação genuinamente brasileira [A genuine Brazilian Research in Communication is missing]. Instituto de Pesquisa Econômica Aplicada (IPEA). https://www.ipea.gov.br/portal/index. php?option=com_content\&view=article\&id=6479\&Itemid=2

Marques de Melo, J. (2009a). Jornalismo, compreensão e reinvenção [Journalism, understanding and reinvention]. São Paulo: Saraiva.

Marques de Melo, J. (2006). Teoria do jornalismo: identidades brasileiras [Theory of journalism: Brazilian identities]. São Paulo: Paulus.

Marques de Melo, J. (2005a). Midiologia para iniciantes [Midiology for beginners]. Caxias do Sul: Educs.

Marques de Melo, J. (2005b). Comunicação Eclesial: utopia e realidade [Ecclesial communication: utopia and reality]. São Paulo: Paulinas.

Marques de Melo, J. (2005c). Exclusión Comunicacional y Democracia Mediatica [Communicative exclusion and media democracy]. In J. M. de Melo, \& L. Sathler. (Eds.), Direitos à Comunicação na Sociedade da informação (pp. 237-244). São Bernardo do Campo: Umesp.

Marques de Melo, J. (2004a). A esfinge midiática [The media sphinx]. São Paulo: Paulus.

Marques de Melo, J. (2004b). Comunicação e evangelização na sociedade global [Communication and Evangelization in global Society]. Estudos de Religião, 17 (26), 14-23.

Marques de Melo, J. (2003). Jornalismo brasileiro [Brazilian journalism]. Porto Alegre: Sulina.

Marques de Melo, J. (2000). Gênese do pensamento comunicacional latino-americano [Genesis of Latin American communicational thinking]. São Bernardo do Campo: UMESP.

Marques de Melo, J. (1992). Gêneros jornalísticos na Folha de São Paulo [Journalistic genres in Folha de São Paulo]. São Paulo: FTD.

Marques de Melo, J. (1991a). Comunicação e modernidade [Communication and modernity]. São Paulo: Paulinas.

Marques de Melo, J. (1991b). Indústria cultural, jornalismo, jornalistas [Culture industry, journalism, journalists]. Revista Intercom, 14 (65), 20-29.

Marques de Melo, J. (1986). Comunicação, direito à informação [Communication, right to information]. São Paulo: Papirus.

Marques de Melo, J. (1985). A opinião no jornalismo brasileiro [The opinion in Brazilian journalism]. Petrópolis: Vozes. 
Marques de Melo, J. (1984). Estado, sociedade civil e comunicação [State, civil society and communication]. Comunicação e Sociedade, 6 (12), 97-102.

Marques de Melo, J. (1981a). Telemania, anestésico social [Telemania, social anesthetic]. São Paulo: Loyola.

Marques de Melo, J. (1981b). Comunicação e libertação [Communication and liberation]. Petrópolis: Vozes.

Marques de Melo, J. (1976). Subdesenvolvimento, urbanização, comunicação [Underdevelopment, urbanization, communication]. Petrópolis: Vozes.

Marques de Melo, J. (1973). Sociologia da imprensa brasileira [Sociology of the Brazilian press]. Petrópolis: Vozes.

Marques de Melo, J. (1972). Estudos de jornalismo comparado [Comparative journalism studies]. São Paulo: Editora Pioneira.

Marques de Melo, J. (1971). Comunicação, opinião, desenvolvimento [Communication, opinion, development]. Petrópolis: Vozes.

Marques de Melo, J. (1970). Comunicação social: teoria e pesquisa [Social communication: theory and research]. Petrópolis: Vozes.

Marques de Melo, J. (1965). Da responsabilidade social no jornalismo [Social responsibility in journalism]. Recife: INCIFORM.

\section{REFERENCES: AUXILIARY STUDIES}

Adorno, S. (1986). Os aprendizes do poder [Power learners]. São Paulo: Paz e Terra.

Ammirato, G. (1963). Homens e jornais [Men and newspapers]. Rio de Janeiro: Aurora.

Aragão, I., Morais, O., Pereira, C., Jaconi, S., \& Gurgel, E. (Org.) (2013). Fortuna crítica de Marques de Melo. (Vols. 1-3). São Paulo: Intercom.

Aragão, I., Morais, O., Pereira, C., Jaconi, S., \& Gurgel, E. (Org.) (2015). Fortuna crítica de Marques de Melo. (Vol. 4). São Paulo: Intercom.

Bahia, J. (2009). Jornal, história e técnica [Newspaper, history and technique] ( $5^{\text {th }}$ ed.). Rio de Janeiro: Mauad. 
Beltrán, L., \& Cardona, E. (1982). Comunicação dominada [Dominated communication]. Rio de Janeiro: Paz e Terra.

Beltrão, L. (1960). Iniciação à filosofia do jornalismo [Introduction to the philosophy of journalism]. Rio de Janeiro: Agir.

Beltrão, L. (2006). Teoria e prática do jornalismo [Theory and practice of journalism]. Adamantina: Omnia.

Bresser-Pereira, L. C. (1984). Development and crisis in Brazil - 19301967. Boulder: Westview Press.

Bresser-Pereira, L. C. (ed.) (2013). O que esperar do Brasil? [What to expect from Brazil?]. Rio de Janeiro: Editora FGV.

Bonet, D. (2004). Humanismo latino e o ensino jurídico no Brasil [Latin humanism and legal education in Brazil]. In L. Bombassaro, A. Dal Ri Junior, \& J. Paviani. (Ed.), As interfaces do humanismo latino. Porto Alegre: Pucrs.

Brito, N. (2018). Luiz Beltrão e os movimentos iniciais da pesquisa em jornalismo no Brasil [Luiz Beltrão and the initial research movements in journalism in Brazil]. Pauta Geral - Estudos Em Jornalismo, 5 (2), 24-40.

Capelato, M. H. (1989). Os arautos do liberalismo [The heralds of liberalism]. São Paulo: Brasiliense.

Dines, A. (1974). O papel do jornal [The role of the newspaper]. Rio de Janeiro: Artenova.

Faoro, R. (1975). Os donos do poder [Masters of the power] (2a ed). Porto Alegre: Globo.

Ferreira, G. (2013). Os estudos de jornalismo comparado [Comparative journalism studies]. In I. Aragão, O. Morais, \& S. Jaconi. (Eds.), Fortuna crítica de Marques de Melo (vol. 1) (pp. 35-44). São Paulo: Intercom.

Furtado, C. (1964). Development and underdevelopment. Berkeley: University of California Press.

Furtado, C. (1973). A hegemonia dos Estados Unidos e o subdesenvolvimento da América Latina. Rio de Janeiro: Civilização 
Brasileira.

Gobbi, M. C. (Org.) (2001). Grandes nomes da Comunicação: José Marques de Melo. Recife: UNICAP.

Gobbi, M. C. (2010). Intellectual Journey of José Marques de Melo: 1959-2009. In A. Hohlfeldt (Ed.), José Marques de Melo, construtor de utopias (pp. 203-229). São Paulo: Intercom.

Goldmann, L. (1969). The Human Sciences and Philosophy. London: Jonathan Cape.

Gomes, P. (2003). José Marques de Melo e a comunicação cristã [José Marques de Melo and Christian communication]. Anuário Unesco Umesp de Comunicação Regional, 7 (7), 171-174.

Guerra, A. (2006). Classe média: desenvolvimento e crise [Middle class: development and crisis]. São Paulo: Cortez.

Habermas, J. (1990). Para a reconstrução do materialismo histórico [For a reconstruction of historical materialism] ( $2^{\text {nd }}$ ed.). São Paulo: Brasiliense.

Habermas, J. (1987). Hermenêutica filosófica: leitura tradicionalista e leitura crítica [Philosophical hermeneutics: traditionalist and critical readings]. Dialética e hermenêutica. Porto Alegre: LP\&M.

Habermas, J. (1983). Interpretive social science vs. hermeneuticism. In N. Haan, R. Bellah, P. Rabinow, \& W. Sullivan. (Eds.), Social science as moral inquiry (pp. 251-267). Nova York: Columbia University Press.

Hohlfedt, A. (2010). José Marques de Melo, construtor de utopias [José Marques de Melo, builder of utopias]. São Paulo: Intercom.

Hohlfeldt, A. (2003). Luiz Beltrão: do jornalismo à literatura [Luiz Beltrão: from journalism to literature]. Revista Brasileira de Ciências da Comunicação, XXVI (1), 69-78. DOI: 10.1590/rbcc.v26i1.1033

Jaguaribe, H. (1962). Desenvolvimento econômico e desenvolvimento político [Economic development and political development]. Rio de Janeiro: Fundo de Cultura.

Matta, F. (1980). A informação na nova ordem internacional [Information in the new international order]. São Paulo: Paz e Terra. 
Mattos, S. (2014). O guerreiro midiático [The media warrior] ( $2^{\text {nd }}$ ed.). São Paulo: Intercom.

Meditsch, E. (2012). Pedagogia e pesquisa para o jornalismo que está por vir. Florianópolis: Insular. [Pedagogy and research for journalism to come]

Mendonça, S. (1986). Estado e economia no Brasil [State and economy in Brazil]. Rio de Janeiro: Graal.

Merquior, J. G. (1991). O liberalismo, antigo e moderno [Liberalism, ancient and modern]. Rio de Janeiro: Nova Fronteira.

Miceli, S. (1979). Intelectuais e classe dirigente no Brasil (1920-1945) [Intellectuals and the ruling class in Brazil (1920-1945)]. São Paulo: Difel.

Mommsen, W. (1981). Pensamiento historico-universal y pensamiento político [Universal-historical thought and political thought]. Max Weber. Barcelona: Laia.

Nogueira, M. (1984). As desventuras do liberalismo [The misfortunes of liberalism]. São Paulo: Paz e Terra.

Peruzzo, C. (2014). Comunicação para o desenvolvimento, comunicação para a transformação social [Communication for development, communication for social transformation]. In M. A. Neto (Ed.), Desenvolvimento nas Ciências Sociais o estado das artes (pp. 161-195). Brasília: Sociedade, Política e Desenvolvimento (IPEA).

Peterson, T. (1956). The social responsibility theory. In F.S. Siebert, T. Peterson, \& W. Schramm (Eds.), Four Theories of the Press (pp. 73103). Urbana: University of Illinois Press.

Paim, A. (1984). História das ideias filosóficas no Brasil [History of philosophical ideas in Brazil]. São Paulo: Convívio.

Popper, K. (1960). The poverty of historicism. London: Routledge.

Porchmann, M. (2015). O mito da classe média [The myth of middle class]. Campinas: Boitempo.

Rabelo, G. (1966). O capital estrangeiro na imprensa brasileira [Foreign capital in the Brazilian press]. Rio de Janeiro: Civilização Brasileira.

Ricœur, P. (1977). Interpretação e ideologias [Interpretation and ideologies]. Rio de Janeiro: Francisco Alves.

Ricúpero, B. (2013). O lugar das ideias [The place of ideas]. Sociologia e antropologia, 3 (6), 523-555. DOI: 10.1590/2238-38752013v368 
Rizzini, C. (1946). O livro, o jornal e a tipografia no Brasil [The book, the newspaper and typography in Brazil]. Rio de Janeiro: Kosmos.

Roth, G., \& Schluchter, W (1979). Max Weber's vision of history. Berkeley: University of California Press.

Sallum Jr., B. (2013). O desenvolvimentismo e o Estado brasileiro contemporâneo [Developmentalism and the contemporary Brazilian state]. Rio de Janeiro: Editora FGV.

Santos, T. (2000). A teoria da dependência - balanço e perspectivas [Dependency theory - balance and perspectives]. Rio de Janeiro: Civilização Brasileira.

Sennett, R. (2006). The culture of the new capitalism. New Haven: Yale University Press.

Sell, C. (2013). Max Weber e a racionalização da vida [Max Weber and the rationalization of life]. Petrópolis: Vozes.

Schwarz, R. (1992). As ideias fora do lugar [Misplaced Ideas]. In Misplaced Ideas (pp. 11-31). London: Verso.

Schwarz, R. (1999). Sequências brasileiras [Brazilian strings]. São Paulo: Cia. das Letras.

Schwartzman, S. (2003). Atualidade de Raymundo Faoro [The actuality of Raymundo Faoro]. Dados - Revista de Ciências Sociais, 46 (2), 207-213. DOI: 10.1590/S0011-52582003000200001

Sodré, N. W. (1998). História da imprensa no Brasil [History of the press in Brazil]. Rio de Janeiro: Mauad.

Sousa, J. P. (2018). A história social da imprensa de José Marques de Melo [José Marques de Melo's social history of the press]. Revista Brasileira de História da Mídia, 7 (2), 2-27. DOI: 10.26664/issn.22385126.7220187614

Sousa, J. P. (2010). José Marques de Melo: Theorist of journalism. In A. Hohlfeldt (Ed.), José Marques de Melo: construtor de utopias (pp. 231-247). São Paulo: Intercom.

Stollmeier, J. C. (1996). O pensamento de José Marques de Melo sobre o relacionamento da Igreja Católica com os meios de comunicação, Congresso Brasileiro de Ciências da Comunicação. São Paulo: Intercom. [José Marques de Melo's thought on the Catholic Church's relationship with the media]

Vizeu, A. (2007). Beltrão, os estudos e as teorias do jornalismo [Beltrão, studies and theories of journalism]. Revista Brasileira de Ciências da Comunicação, 3 (1), 13-34. DOI: 10.1590/rbcc.v30i1.278 
FRANCISCO RÜDIGER. PhD in Social Sciences from the University of São Paulo. Professor of the Postgraduate Program in Communication at the Pontifical Catholic University of Rio Grande do Sul, and in the philosophy department at the Federal University of Rio Grande do Sul. Researcher at the National Council for Scientific and Technological Development. E-mail: frudiger33@gmail.br

OTÁVIO DAROS. PhD student at the Postgraduate Program in Communication at the Pontifical Catholic University of Rio Grande do Sul. Fellowship in the Communication History and Media Change Lab at the University of Bremen. E-mail: otavio.daros@gmail.com

Translated by: Otávio Daros and Francisco Rüdiger 